Journal of Urban and Regional Analysis, vol. XIII, 1, 2021, p. $35-57$

https://doi.org/10.37043/JURA.2021.13.1.3

\title{
A MULTI-MODEL APPROACH TO ASSESS THE RELATIVE WEIGHTS AND SENSITIVITIES OF THE FACTORS OF REGIONAL COMPETITIVENESS
}

\author{
Shahid RAHMAT, Joy SEN \\ Indian Institute of Technology, Kharagpur, India
}

\begin{abstract}
In order to prioritize the intervention to augment regional competitiveness, it is essential to assess the relative weights and sensitivities related to the factors of competitiveness. The improper assignment of relative weights is prominent in the case when multi-co-linearity exists among independent variables. The paper tests the suitability of multiple models for their capacity of assessing relative weights, and subsequently for forming a competitiveness index. The relative weights of critical components of economic infrastructure have been assessed with Zero-order correlation, Structure coefficient analysis, Beta coefficient analysis, Product measure analysis, Relative weight analysis, and Commonality analysis. Subsequently, regional competitiveness indices have been formed with relative weights as a linear combination. The most suitable technique to form an index has been identified through the Pearson correlation and Spearman rank correlation analyses. The multiple regression analysis assigns the relative weights and consecutively forms the regional competitiveness index, better than other applied techniques. Zero-order correlation and Structural coefficient analysis performed reasonably well. Commonality analysis is a very appropriate technique for the detailed investigation of unique and shared effects among variables. The result shows that the common effects of the critical components of the economic infrastructure are stronger than their unique effects. The sensitivity of competitiveness related to the variables has been assessed through Artificial Neural Network. Regional competitiveness is most sensitive to the variable of rural roads. The results indicate that better connectivity triggers capital and labor drain from the rural areas of the region.
\end{abstract}

Key Words: regional competitiveness, economic infrastructure, multi-model approach, artificial neural network.

\section{Introduction}

To augment the regional economy, the assessment and enhancement of regional competitiveness are very crucial (Rahmat and Sen 2016). Better competitiveness is a prerequisite for economic development (Yaskal et al. 2018), and it enhances the economy of a country (Bhawsar and Chattopadhyay 2015). Geographical competitiveness is essential to attract and maintain firms, and to improve the standard of living of the participants (Storper 1997). Improvement in the level of competitiveness is a continuous process (Somoza Medina 2016). Porter (1990) argues that competitiveness is a dynamic process, and it depends on the ability to improve with time. There are various levels at which competition happens (Simionescu 2016). Region/cities fall between the highest macro-level (country) and lowest micro-level (firm) (Cellini and Soci 2002). Out of the various levels, regions are the crucial source of competition. Porter $(1990,1998)$ also supports the region as an originating location of competitiveness. The competitiveness of an economy is suppressed due to inequality in the competitive performance of different regions (Staníčková et al. 2012). Regional competitiveness is defined as how firms in a particular region can compete with the firms in other regions (Purwanto et al. 2017). Competitive regions have a better standard of living and a conducive business environment (Birnie et al. 2019). Some common factors are present in each region to influence the competitiveness of all firms (Simionescu 2016). The natural and other resources present in a region enhance the competitiveness of the region (Yaskal et al. 2018). 
Two sets of indicators explain the competitiveness of a geographical territory. Firstly, the term 'revealed competitiveness' is the construct that represents the meaning of competitiveness most appropriately. Secondly, 'factors of competitiveness' represent the set of indicators that builds the 'revealed competitiveness' of a geographical territory. Most researchers agree that the term 'revealed competitiveness' is best represented by the notion of 'productivity' (Krugman 1997, Gardiner et al. 2004, Kitson et al. 2004). To measure the 'revealed competitiveness,' per capita GDP is the indicator (Huovari et al. 2002, Huggins 2003, Martin 2003, Kovacs and Lukovics 2006, Porter et al. 2008). Dunning et al. (1998) also observe that per capita GDP is a critical indicator of competitiveness. According to Snieška and Bruneckien (2009), per capita GDP is the most frequently utilized indicator of competitiveness. Other researchers have also discussed the relationship between competitiveness and GDP (Civelek et al. 2015).

Competitiveness is a multidimensional concept (García-Sánchez et al. 2018). There are different categories of the factors of competitiveness (Popescu et al. 2017). An enhanced level of competitiveness is the aggregated effect of these factors (Stanickova 2015). 'Factors of competitiveness' have been explained in literature through various models. Some of the most cited models in literature are the Diamond model (Porter 1990, Castro-Gonzáles et al. 2016), the Pyramid model (Lengyel 2007), the Regional competitiveness hat model (Martin 2003), and the Hierarchical model (Singhal et al. 2013). In all the above-described models, infrastructure is a crucial component of the factors of competitiveness. The regional competitiveness hat model provides a list of determinants of regional competitiveness and it puts infrastructure in the second ring (Martin 2003). The Pyramid model of regional competitiveness puts the infrastructure among the five essential development factors (Lengyel 2007). The World Economic Forum (Schwab 2016), for factor-driven economies (India falls in this stage), assigns higher weights to institutions, infrastructure, and few other factors. Inadequate supply of infrastructure is among the most problematic factors for doing business in India (Schwab 2016, World Bank Group 2016). Infrastructure enhances productivity (Kaur et al. 2016), and the competitiveness of a region (Achour and Belloumi 2016). More specifically, economic infrastructure enhances the productivity of capital and labor (Kumari and Sharma 2017). Fourie (2006) defines economic infrastructure as an infrastructure that supports the economic activities of a region. According to the World Bank (1994), economic infrastructure can be defined as the facilities used in the production process. The present paper analyzes the effect of the selected components of economic infrastructure on the competitiveness of regions.

The above-discussed factors of competitiveness have a different level of presence in a region, and they together enhance the competitiveness of a region. Regions having a lower level of factor endowment show a lower attractiveness for capital and labor and they are less competitive as a result. These regions have few income-generating sources, and they fall into the cycle of a lower level of competitiveness. These regions lose their capital and labor in the favor of regions having a higher level of development (Chase-Dunn 1975, Chen and Partridge 2013). Understanding of relative weights and sensitivities of factors of competitiveness is essential to prioritize the investment in infrastructure within the financial limitations of public institutions (Nagaraj et al. 2000, Cai and Treisman 2005) for better factor endowment. A methodology and a review on the existing methods to assess the relative weights are provided in the subsequent sections.

\section{Methodology \\ Study area}

A region belonging to the fertile plain of northern and eastern India is selected to study the effect of economic infrastructure on regional competitiveness (Fig. 1). The region belongs to the Indo-Gangetic plain (IGP). It was delineated by the application of cluster analysis for the share of six sectors of the economy in the Gross Domestic Products of 531 districts of India (Rahmat and Sen 2016). The region contains 81 agriculture-based districts (thirty-seven 
districts of Uttar Pradesh, twenty-eight districts of Bihar, eleven districts of West Bengal, and five districts of Northern Madhya Pradesh).

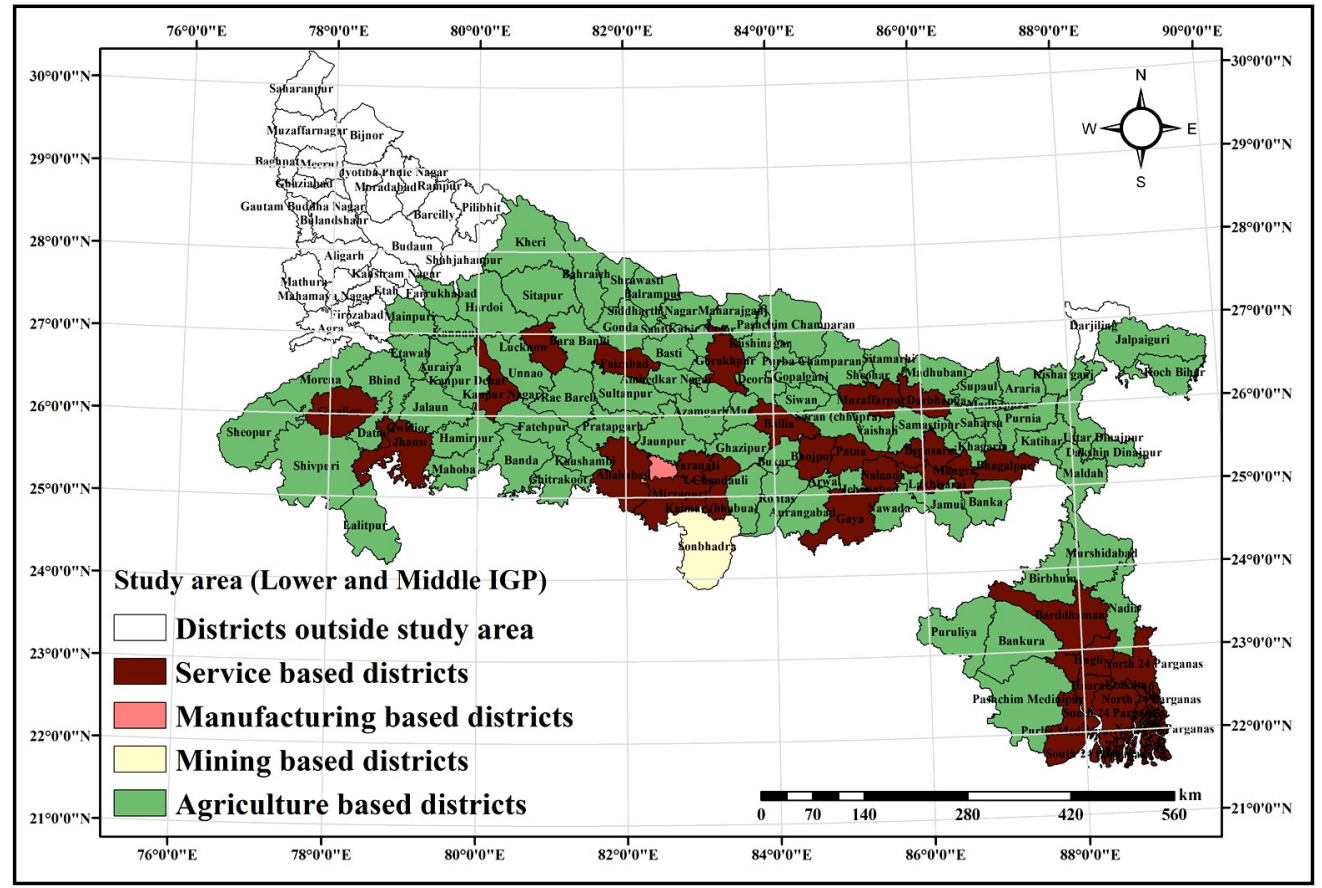

Fig. 1 - The analysed region with the classification of districts based on the economic structure

The per capita GDP in the region is lowest for Sheohar of Bihar (105.1 USD) and highest for Jalpaiguri of West Bengal (462.7 USD). The share in per capita GDP of the region is highest for agriculture and allied activities (India's average $-18.9 \%$, region $-39.79 \%$ ).

\section{Regional competitiveness assessment}

In order to prioritize the intervention to augment regional competitiveness, it is crucial to estimate the relative weights and sensitivities of the factors of competitiveness. Firstly, a list of indicators has been prepared for the critical components of economic infrastructure through a review of the literature and an experts'/stakeholders' opinion survey. Zero-order correlation, Structure coefficient analysis, Beta coefficient analysis, Product measure analysis, Relative weight analysis, and Commonality analysis have been applied to estimate the relative weights of the selected critical components of economic infrastructure in the augmentation of regional competitiveness. Each of the methods estimates the relative weights differently and it provides inconsistent results. The possible reason for the inconsistency in the results is the suppression effect. Some of the variables strip other variables of the shared variance and they become more critical. Different techniques assign the shared variance differently; a variable keeps changing its relative importance with other variables. Therefore it becomes necessary to apply multiple techniques to estimate the relative weight and then to test the results obtained from the techniques. 
Subsequently, with the relative weights obtained from the above-described analyses, indices have been formed. These indices have been put to Pearson's correlation and Spearman's correlation with the indicator of revealed regional competitiveness. Finally, to analyze the possible changes in regional competitiveness as a result of the changes in the indicators of economic infrastructure, the sensitivity analysis has been performed through the Artificial Neural Network (ANN). The methodology for the paper is presented in Fig. 2.

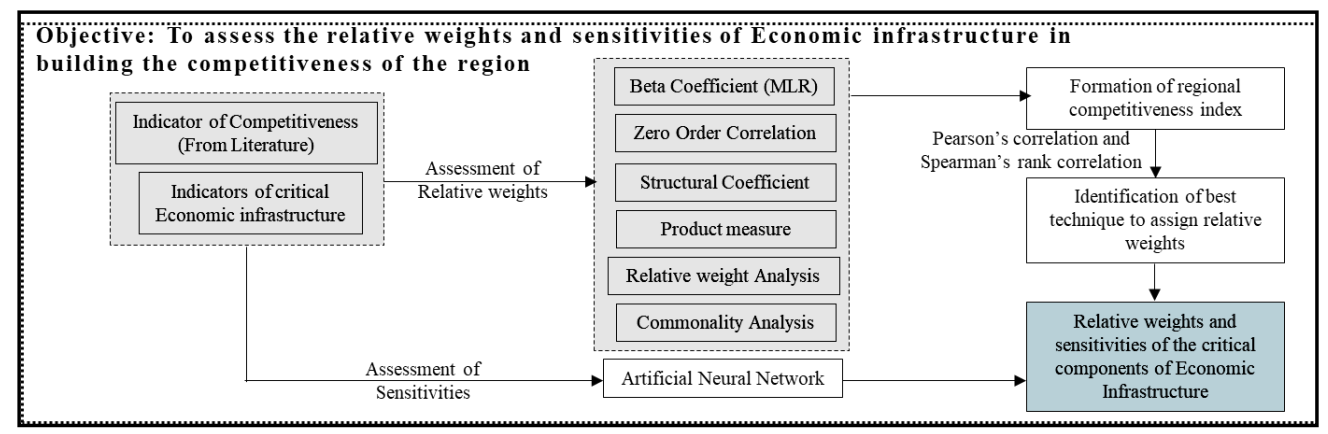

Fig. 2 - Methodology

Review of existing methods

The existing literature has applied different techniques to assign relative weights to the indicators and subsequently for the formation of an index. Huoveri et al. (2002) formulated a competitiveness index through the average values of the indicators. Booysen (2002) and Freudenberg (2003) emphasized on the assignment of different weights to the indicators for the precise formation of a competitive index. Two sets of techniques are used in the academic literature for the assessment of relative weights.

In the first set of techniques, the opinion of experts and stakeholders are utilized for the assessment of relative weights (Schwab et al. 2002, Snieška and Bruneckien 2009, Schwab 2016). Kiszova and Nevima (2012) applied the Analytic hierarchy process (pairwise comparison) to the opinion of experts to calculate the relative weights of the factors of competitiveness. Singhal et al. (2013) applied the Delphi technique to collect the opinion of experts for the competitiveness of UK cities. Čučković et al. (2013) asked experts regarding the strengths and weaknesses of the region. OECD (2008) applied the Budget allocation technique based on the public's concerns regarding a few selected issues. Hair et al. (1995) and McDaniel and Gates (1998) utilized a multivariate data analysis technique called the Conjoint analysis. Few researchers used the Multi-criteria decision analysis to choose, rank, and sort alternative priorities (Fernandez et al. 2013). Few researchers utilized AHP for the assessment of regional competitiveness (Kramulová and Jablonský 2016). A Hybrid AHP has been used to evaluate tourism competitiveness (Zhou et al. 2015).

In the second set of techniques, relative weights are estimated on the secondary data of the indicators. Few researchers applied the linear correlation analysis to assess the relative weights of the factors of competitiveness (Lengyel and Lukovics 2006, Barna 2007, Mikuš et al. 2012). Mikuš et al. (2012) analyzed the rural competitiveness of Croatia through the correlation analysis. Few have applied the correlational analysis to form an index (Moseiko et al. 2015). Few have applied the factor analysis based on the Regional competitiveness index (Stanickova 2015). The factor analysis is applied for the dimension reduction of the factors of competitiveness (Barkley and Dudensing 2011). Few of the researchers used the simple linear regression for the estimation of weights (Petrarca and Terzi 2018). Some other researchers 
used the multiple regression analysis (MLR) to estimate the relative weights (Wong 2002, Porter et al. 2004, Kovacs and Lukovics 2006). Few studies utilized MLR for the formation of competitiveness index (Bowen and Moesen 2011). MLR was utilized to assess the effect of infrastructure on competitiveness (Palei 2015). Guerrero et al. (2016) used the correlation analysis supplemented by the factor analysis. Ju and Sohn (2014) applied the structural equation modeling (SEM) to form a competitiveness index.

In the present paper, the Beta coefficient, Zero-order correlation, Structure coefficient, Product measure, Relative weight analysis, and Commonality analysis have been applied to assess the relative weights of the selected critical components of economic infrastructure in the augmentation of regional competitiveness. Subsequently, indices have been formed, utilizing the weights obtained from the analyses mentioned above. The indices have been correlated with the indicator of competitiveness through the Pearson correlation analysis and the Spearman rank correlation analysis to identify the most appropriate technique. A brief discussion on the methods of assessment of relative weights utilized in the paper is provided in the subsequent sections.

\section{Selection of indicators}

Policies of regional competitiveness have been urban-centric. Whereas, the importance of villages in regional competitiveness is getting critical with time (Schwab 2016). Other researchers also recognized the need for the involvement of rural areas in regional competitiveness (Devereux et al. 2004, Thompson and Ward 2005). Recently, Europe's rural areas have been the focus of competitiveness policies (Schaller et al. 2018). The research has shown that the inclusion of rural infrastructure is essential for the competitiveness of the region, especially if the region is predominantly agriculture-based. Also, in the era of modernization and openness to information and technology, traditional sectors like agriculture need to be understood both from the perspective of demand and supply. These sectors should not be judged only based on the level of their output. The role of local and regional infrastructure differs in the context of regional competitiveness. A case study in the present research has the lowest level of competitiveness in India; hence, only the most critical, regional economic infrastructure has been selected in the research. Local economic infrastructure, like water supply, drainage, and others, is essential and it can be critical in the context of other regions, depending on the requirements of the region. The paper utilizes rural and urban components of infrastructure separately in the analysis of regional competitiveness.

\section{Assessment of relative weight}

The multiple linear regression analysis is the standard technique to estimate the relative weights in the case when the dependent and independent variables are known. It is utilized to calculate the relative weights of variables (Nathans et al. 2012). In the multiple regression analysis, researchers commonly use the beta weight for the measurement of relative weights (Zientek et al. 2008, Nimon et al. 2010, Nimon and Reio 2011). The Beta weight is the indicator of the total effect of a variable (LeBreton et al. 2004).

Due to multi-co-linearity among variables, beta weights become unreliable (Courville and Thompson 2001). For example, three independent variables, IV1, IV2, and IV3, share a certain percentage of variance with the dependent variable DV (Fig. 3). Due to the presence of multicollinearity among the independent variables, variances S12, S13, S23, and S123 are shared by variables (IV1 \& IV2), (IV1 \& IV3), (IV2 \& IV3), and (IV1, IV2 \& IV3), respectively. These shared variances are assigned randomly to any of the independent variables. A particular beta weight may receive extra credit for the variance it shares with other independent variables (Pedhazur 1997). An independent variable that shares a small variance with the dependent variable can have a significantly large beta weight. This extra variance can be the shared 
portion of the variance assigned to this particular independent variable and it increases its predictive power (Capraro and Capraro 2001). This process is called the 'suppression' effect. To identify the suppressor variables and to estimate the relative weights of the variables more accurately, some of the accepted techniques are followingly mentioned.

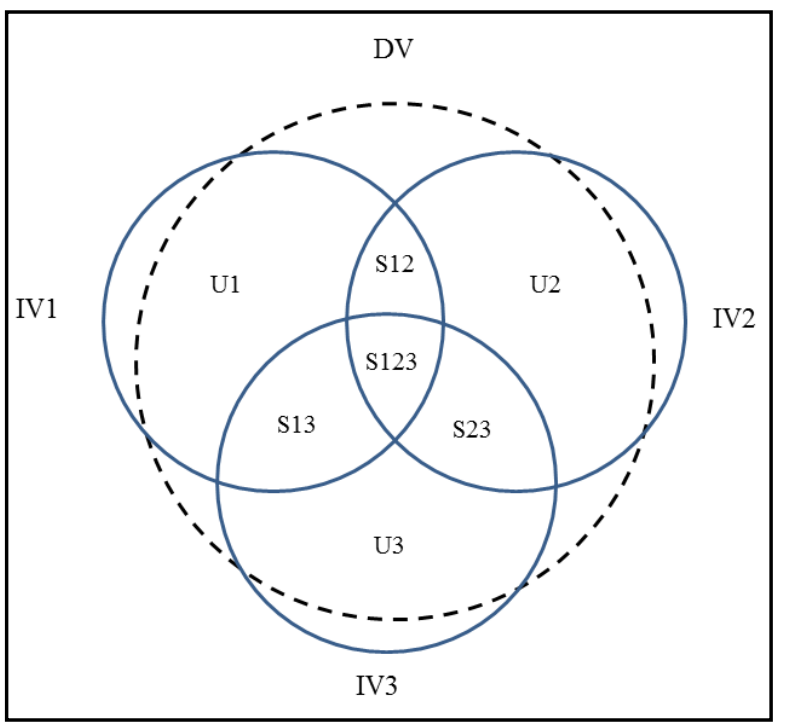

Fig. 3-Venn diagram showing the unique and shared variances

\section{Zero-order correlation}

The Zero-order correlation estimates the impact of an independent variable on a dependent variable (LeBreton et al. 2004). The Zero-order correlation is not affected by the presence of other variables in the model (LeBreton et al. 2004). Hence, it remains unaffected by multicollinearity among the independent variables (Kraha et al. 2012). A variable can have insignificant beta weight but a high zero-order correlation due to the variance it shares with other variables (Nunnally and Bernstein 1994). The variable with a small zero-order correlation and a significantly high beta weight can be a suppressor variable (Nathans et al. 2012). Suppressor variables strip shared variance from other variables in the model (Nathans et al. 2012).

\section{Structure Coefficient}

The Structure coefficient is the correlation between an independent variable and an estimated dependent variable (Courville and Thompson 2001). A structure coefficient is the measure of the direct effect of the variables in the model (LeBreton et al. 2004). The structure coefficient is not affected by the multi-collinearity among variables (Courville and Thompson 2001, Ziglari 2017). Structure coefficients are very useful as a measure of relative weight in the presence of multi-collinearity among the variables in the model (Kraha et al. 2012). A variable having insignificant beta weight but having a large squared structure coefficient is the suppressed variable, which loses its shared portion of variance (Nathans et al. 2012). The squared structure coefficient indicates how much variance of $\mathrm{R}$-squared a variable can explain (Zientek and Thompson 2006). 


\section{Product Measure}

The product measure is assessed through the multiplication between zero-order correlation and its beta weight (Pratt 1987). It reflects both direct and total effects (LeBreton et al. 2004). It partitions the regression effect. $R^{2}$ is equal to the sum of product measures of all the predictor variables (Azen and Budescu 2003). In case one of the zero-order correlation or beta weight is less than zero, the product measure gives a negative coefficient for the predictor variables (Darlington 1968). The product measure's significant advantage is to partition the R-squared, even for the correlated variables (Azen and Budescu 2003). The disadvantage of product measure is that it provides negative coefficients if either the zero-order correlation or beta coefficient is negative (Darlington 1968).

\section{Relative weight analysis}

The Relative weight analysis minimizes the impact of multi-co-linearity among the variables (Johnson and LeBreton 2004). The relative weight is calculated differently when the independent variables are correlated and when they are uncorrelated. When uncorrelated, the calculation of relative weight is performed with the help of the squared zero-order correlation and $R^{2}$ (Johnson 2000). When correlated, the relative weight is calculated with the principal components analysis and a series of regression analyses (Tonidandel and LeBreton 2010). The weights obtained through the relative weight analysis can only be partially affected by the correlation among the variables (Nathans et al. 2012). The relative weight analysis is utilized to analyze the contribution of each of the independent variables in the model rather than to rank the variables (Johnson 2000). Few other researchers also utilized the Relative weight analysis for the calculation of the weights of multiple variables (Tonidandel and LeBreton 2015).

\section{Commonality Coefficients}

The Commonality analysis partitions $\mathrm{R}^{2}$ in unique and shared components (Rowell 1996). The Commonality analysis partitions the total effect in parts that do not overlap (Nathans et al. 2012). For example, if we predict the effects of IV1, IV2, and IV3 on DV. The Commonality analysis calculates the variance in DV that is predicted by unique variances of $U 1, U 2$, and U3; and by shared variances of (S1 \& S2), (S1 \& S3), (S2 \& S3), and (S1, S2, \& S3). The number of commonality coefficients increases rapidly with the count of variables (Mood 1971). The number of coefficients is 7,15 , and 31 , with three, four, or five independent variables, respectively (Nathans et al. 2012). The major disadvantage of commonality analysis is that, with the increase in the number of variables, the number of commonality coefficients increases exponentially (Mood 1971). It can provide the effects of targeting more than one variable (Nathans et al. 2012). Commonality analysis can identify the suppressor variables and the suppression effect (Nathans et al. 2012).

The above-discussed techniques have been applied to estimate the relative weights of the selected critical components of economic infrastructure in the paper.

\section{Assessment of sensitivity}

The Sensitivity analysis has been performed with the Artificial Neural Network (ANN) to analyze the possible changes in the value of regional competitiveness with the changes in economic infrastructure. ANN mimics the human brain to estimate the relationship between inputs and outputs (Zhou et al. 2009). A trained ANN can predict a relationship for a new input data-set (Heravi and Eslamdoost 2015). ANN is utilized for training and the consecutively estimation of an output for an input (Toghyani et al. 2016). The Neural Network predicts the output for a set of given inputs (Olden and Jackson 2002). Few researchers have applied this 
property of ANN for estimating sensitivity (Olden and Jackson 2002). Sensitivity provides the relative importance of the variables (Nasseri et al. 2008). In the analysis, the values of each of the variables are increased, one by one (Olden and Jackson 2002). For the analysis, data is normalized in the interval of $(0,1)$ (Zhou et al. 2009). The multilayer feed-forward neural networks are the most frequently applied ANN (Tam et al. 2002). Early stopping and Bayesian regularization are used to reduce over-fitting and for the improvement of generalization (Heravi and Eslamdoost 2015).

\section{Pre-processing of data}

The data had been pre-processed before the estimation of relative weights. The tests of normality and multi-co-linearity have been performed in this phase of analysis.

\section{Test of Normality}

The indicators for the critical components of economic infrastructure have been selected through an extensive literature survey (Table 1). The normality of variables has been tested in IBM SPSS 22. Standardized ( $\mathrm{z}$ ) values of skewness and kurtosis have been calculated by dividing their statistics by their standard error, respectively (Hopkins and Weeks 1990, Kim 2013). Outliers have been identified with box-plots. Few of the variables (HWY, ELU, ELR, INU, TPU, TPR, LRL, and LRR) are non-normally distributed (absolute z-value for either skew-ness or kurtosis or both are larger than 1.96). Winsorizing is the standard method of eliminating outliers (Yaffee 2002, Ghosh and Vogt 2012). In Winsorization, the outlier's value is replaced by a suitable value (Watson 1990, Ghosh and Vogt 2012). Outliers have been replaced by the 5 th and 95th percentile values of the respective variable. After replacing outliers, the $z$-values of skewness and kurtosis of each variable came within the acceptable limit.

Table 1

Critical components of economic infrastructure and their indicators

\begin{tabular}{|c|l|l|c|}
\hline $\begin{array}{c}\text { SI. } \\
\text { No. }\end{array}$ & \multicolumn{1}{|c|}{ Construct } & \multicolumn{1}{c|}{ Indicator } & $\begin{array}{c}\text { Abbrevia- } \\
\text { tion }\end{array}$ \\
\hline 1 & Regional Road Infrastructure & Length of Highways per 1000 sq. km of area & HWY \\
\hline 2 & Electricity Infrastructure & $\begin{array}{l}\text { Percentage of urban households having ac- } \\
\text { cess to electricity }\end{array}$ & ELU \\
\hline 3 & Electricity Infrastructure & $\begin{array}{l}\text { Percentage of rural households having access } \\
\text { to electricity }\end{array}$ & ELR \\
\hline 4 & Mobile Phone Infrastructure & $\begin{array}{l}\text { Percentage of urban households having mo- } \\
\text { bile phones }\end{array}$ & MPU \\
\hline 5 & Mobile Phone Infrastructure & $\begin{array}{l}\text { Percentage of rural households having mobile } \\
\text { phones }\end{array}$ & MPR \\
\hline 6 & Internet Infrastructure & $\begin{array}{l}\text { Percentage of urban households having a } \\
\text { computer/laptop with internet }\end{array}$ & INU \\
\hline 7 & Internet Infrastructure & $\begin{array}{l}\text { Percentage of rural households having a com- } \\
\text { puter/laptop with internet }\end{array}$ & INR \\
\hline 8 & Road Infrastructure & Total Length of road per thousand sq. km. & TLR \\
\hline 9 & Landline Infrastructure & $\begin{array}{l}\text { Percentage of urban households having a } \\
\text { landline telephone }\end{array}$ & TPU \\
\hline 10 & Landline Infrastructure & $\begin{array}{l}\text { Percentage of rural households having a land- } \\
\text { line telephone }\end{array}$ & $\begin{array}{l}\text { Length of Railway lines per 1000 sq. km of } \\
\text { area }\end{array}$ \\
\hline 11 & Railway Infrastructure & $\begin{array}{l}\text { Total Length of Rural road per thousand sq. } \\
\text { km. of rural area }\end{array}$ & LRL \\
\hline 12 & Rural Road Infrastructure & LRR \\
\hline
\end{tabular}




\section{Exploration of Multi-collinearity}

Multi-co-linearity is the presence of a high correlation among the variables (Disatnik and Sivan 2016). Variance Inflation Factor (VIF) $>4$ indicates a very high level of multi-co-linearity (O'Brien 2007). Six variables in the study have VIF $>4$. Multi-co-linearity in the data justifies the underlying assumption of the paper and it explains the requirement of a detailed investigation.

\section{Results}

All the six techniques, viz., beta coefficient, zero-order correlation, structure coefficient analysis, product measure analysis, relative weight analysis, and commonality coefficient analysis, have been performed. These analyses have been performed to assess the relative weights of selected factors of competitiveness (critical components of economic infrastructure) as independent variables and the indicator of revealed competitiveness (per capita GDP) as a dependent variable.

LRR (rural road), ELR (rural electricity) and TLR (rural landline) are the most critical and LRL (railway infrastructure), INU (urban internet), and TPU (urban landline) are the least essential components of economic infrastructure according to the zero-order correlation. The parameter estimation of zero-order correlation shows negative coefficients for eight variables. According to the zero-order correlation, rural infrastructure is more important than urban infrastructure for the competitiveness of the region (Table 2).

Table 2

\section{Values of the coefficients}

\begin{tabular}{|c|c|c|c|c|c|c|c|c|}
\hline $\begin{array}{l}\text { Indi- } \\
\text { cator }\end{array}$ & $\begin{array}{c}\text { Zero- } \\
\text { order } \\
\text { corre- } \\
\text { lation }\end{array}$ & $\begin{array}{c}\text { Struc- } \\
\text { ture } \\
\text { coeffi- } \\
\text { cient }\end{array}$ & $\begin{array}{c}\text { Beta } \\
\text { coeffi- } \\
\text { cient }\end{array}$ & $\begin{array}{c}\text { Product } \\
\text { measure }\end{array}$ & $\begin{array}{c}\text { Rela- } \\
\text { tive } \\
\text { weight }\end{array}$ & $\begin{array}{c}\text { Unique } \\
\text { effect }\end{array}$ & $\begin{array}{c}\text { Common } \\
\text { effect }\end{array}$ & $\begin{array}{c}\text { Total } \\
\text { effect }\end{array}$ \\
\hline HWY & -0.476 & -0.574 & -0.176 & 0.084 & 0.123 & 0.021 & 0.205 & 0.226 \\
\hline ELU & 0.492 & 0.593 & -0.018 & -0.009 & 0.254 & 0.000 & 0.242 & 0.242 \\
\hline ELR & 0.609 & 0.734 & 0.386 & 0.235 & 0.380 & 0.050 & 0.321 & 0.371 \\
\hline MPU & -0.233 & -0.281 & 0.063 & -0.015 & 0.062 & 0.001 & 0.054 & 0.054 \\
\hline MPR & -0.437 & -0.526 & -0.291 & 0.127 & 0.054 & 0.008 & 0.182 & 0.191 \\
\hline INU & 0.112 & 0.135 & 0.063 & 0.007 & 0.022 & 0.001 & 0.011 & 0.013 \\
\hline INR & -0.303 & -0.366 & -0.298 & 0.090 & 0.039 & 0.013 & 0.079 & 0.092 \\
\hline TLR & -0.542 & -0.654 & -0.103 & 0.056 & 0.234 & 0.003 & 0.291 & 0.294 \\
\hline TPU & -0.037 & -0.045 & 0.009 & 0.000 & 0.014 & 0.000 & 0.001 & 0.001 \\
\hline TPR & -0.228 & -0.275 & 0.452 & -0.103 & 0.024 & 0.026 & 0.026 & 0.052 \\
\hline LRL & 0.159 & 0.192 & 0.089 & 0.014 & 0.027 & 0.006 & 0.020 & 0.025 \\
\hline LRR & -0.644 & -0.776 & -0.313 & 0.202 & 0.155 & 0.023 & 0.391 & 0.414 \\
\hline
\end{tabular}

The rank order estimated by the structure coefficient analysis is similar to the rank order estimated by the zero-order correlation analysis, with slightly higher values of coefficients. The parameter estimation of the structure coefficient analysis also shows negative coefficients for eight variables. In the analysis, rural infrastructure is more critical than urban infrastructure for the competitiveness of the region.

The parameter estimation of the beta coefficient demonstrates that, in the multivariate framework, the variables explain $68.8 \%$ of the variance (R-square $=0.688$, Adjusted Rsquare $=0.633$ ). ANOVA is significant at 0.00 levels. The null hypothesis has been rejected for 
the slope of the regression line is zero. TPR (rural landline), ELR (rural electricity), and LRR (rural road) are the most critical and MPU (urban mobile phone), ELU (urban electricity), and TPU (urban landline) are the least significant components of economic infrastructure. Six indicators of economic infrastructure are negatively associated with the per capita GDP. The analysis also shows that rural infrastructure is more critical than urban infrastructure.

ELR (rural electricity), LRR (rural road), and MPR (rural mobile phone) are the most critical and ELU (urban electricity), INU (urban internet), and TPU (urban landline) are the least significant components of economic infrastructure according to the product measure analysis. The rankordering obtained from the Product measure analysis is very different from the zero-order correlation, the structure coefficient, and the beta coefficient. The analysis shows mixed importance for urban and rural infrastructures. The parameter estimate of product measure analysis shows negative coefficients for three variables and, hence, it cannot be used as a measure of variable importance in the present case because of the improper partitioning of Rsquare.

According to the relative weight analysis ELR (rural electricity), ELU (urban electricity), and TLR (rural landline) are the most critical and TPR (rural landline), INU (urban internet), and TPU (urban landline) are the least significant components of economic infrastructure for the region. In this analysis, rural infrastructure is more critical than the urban infrastructure. The relative weight analysis provides different results from the earlier described analyses.

The commonality analysis has been performed with the syntax provided by Nimon (2010). LRR (rural road), ELR (rural electricity), and TLR (rural landline) are the most essential and LRL (railway), INU (urban internet), and TPU (urban landline) are the least significant components of economic infrastructure according to the total effect of commonality analysis. The rank order obtained from the analysis is precisely similar to the zero-order correlation and the structure coefficient analysis. According to the commonality analysis, rural infrastructure is more critical than urban infrastructure. For all the variables, a larger share of the total effect is contributed by the common effect than the unique effect, which these variables share with other variables. The result implies that the policy of jointly targeting the components of infrastructure is the most appropriate for the region.

The commonality analysis provides a detailed list of unique and shared coefficients and the shared variances. In the present case, it provides a total of 4095 numbers of such coefficients. For example, the variable ELR (rural electricity) uniquely shares $7.29 \%$ variance, \{variables TLR (rural telephone) and LRR (rural road)\} jointly share $7.16 \%$ variance, \{variables ELU (urban electricity) and ELR (rural electricity)\} jointly share $6.49 \%$ variance and variables $\{\mathrm{HWY}$ (highway density), ELU (urban electricity), and ELR (rural electricity)\} jointly share $5.56 \%$ variance with the dependent variable. Out of the total of 4095 coefficients, the 22 most critical coefficients share $79.0 \%$ of the total extracted variance (Table 3 ).

Python with Pandas data frame and Mat-plot-lib was utilized to automate the process of visualization of the distribution of the cumulative coefficient and the cumulative percentage value of the commonality matrix arranged in the decreasing order of percentage share (Fig. 4). For up to 286 number of coefficients, the curve shows an increasing trend (value of coefficients $>0$ ). Afterward, it becomes parallel to the $x$-axis (value of coefficients $=0$ ). After 2411 number of coefficients, the curve bends downwards (value of coefficients $<0$ ). Negative commonality coefficients are explained in literature in different ways. Pedhazur (1997) explains it as the result of the suppression effect or the effect of predictors in the opposite direction. According to Frederick (1999), a negative value of the commonality coefficient can be treated as zero. 


\section{Partial commonality matrix}

\begin{tabular}{|c|l|c|c|}
\hline Rank & \multicolumn{1}{|c|}{ Indicator (Abbreviation) } & Coefficient & Percent \\
\hline 1 & Unique to ELR & 0.0502 & 7.2946 \\
\hline 2 & Common to TLR \& LRR & 0.0493 & 7.1616 \\
\hline 3 & Common to ELU \& ELR & 0.0447 & 6.4989 \\
\hline 4 & Common to HWY, ELU \& ELR & 0.0383 & 5.5689 \\
\hline 5 & Common to LRR \& ELR & 0.0368 & 5.3543 \\
\hline 6 & Common to TLR, HWY, LRR, ELU \& ELR & 0.0265 & 3.8506 \\
\hline 7 & Unique to TPR & 0.0256 & 3.7150 \\
\hline 8 & Common to TLR, LRR, MPR, INR, ELU \& ELR & 0.0242 & 3.5215 \\
\hline 9 & Unique to LRR & 0.0231 & 3.3577 \\
\hline 10 & Common to TLR, LRR \& ELR & 0.0224 & 3.2617 \\
\hline 11 & Unique to HWY & 0.0213 & 3.0932 \\
\hline 12 & Common to TLR, LRR, TPR, MPU, MPR \& INR & 0.0192 & 2.7842 \\
\hline 13 & Common to TLR, HWY, LRR, TPR, MPU, MPR \& INR & 0.0180 & 2.6111 \\
\hline 14 & Common to TLR, HWY, LRR, MPR, ELU \& ELR & 0.0172 & 2.4985 \\
\hline 15 & Common to TLR, HWY, LRR, TPR, MPR, INR, ELU \& LER & 0.0172 & 2.4940 \\
\hline 16 & Common to TPR, ELU \& ELR & 0.0169 & 2.4507 \\
\hline 17 & Common to LRR, MPU, ELU \& ELR & 0.0165 & 2.4029 \\
\hline 18 & Common to TLR, LRR, MPR, ELU \& ELR & 0.0160 & 2.3218 \\
\hline 19 & Common to LRR, MPR, ELU \& ELR & 0.0159 & 2.3119 \\
\hline 20 & Common to LRR \& MPR & 0.0158 & 2.2955 \\
\hline 21 & Common to TLR, LRR \& MPR & 0.0144 & 2.0877 \\
\hline 22 & Common to TLR, HWY \& LRR & 0.0142 & 2.0707 \\
\hline & Total & 79.0072 \\
\hline
\end{tabular}

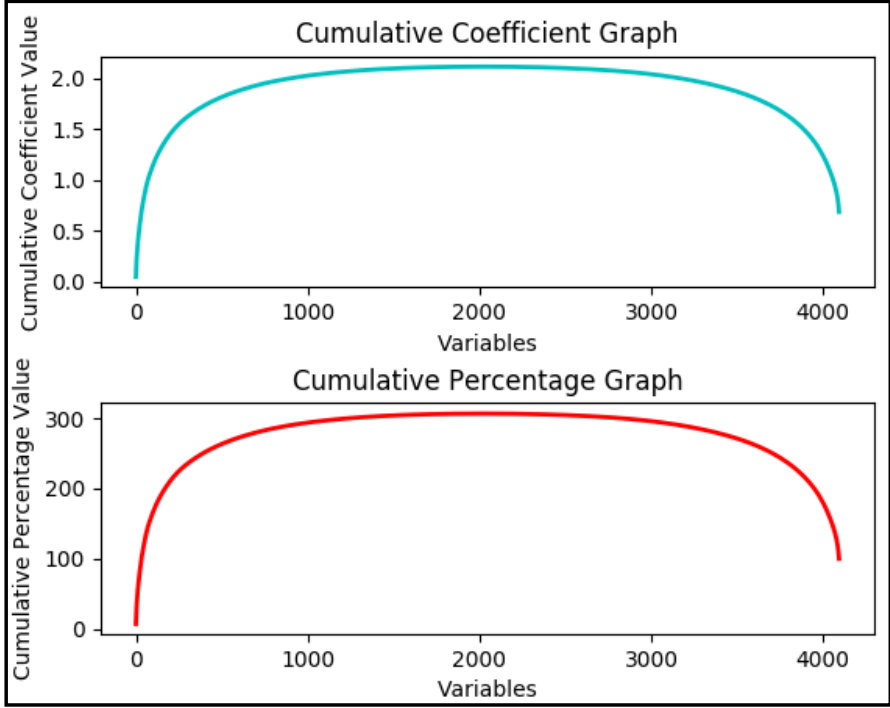

Fig. 4 - Cumulative coefficient and its percentage share in the commonality matrix 
Inconsistency in the results

The relative weights and ranking of all variables are inconsistent among all applied techniques. For example, variable LRR (rural road) shifted from the most critical independent variable in the zero-order correlation, the structure coefficient analysis, and the total effect of commonality analysis to the third position in MLR, the second position in product measure, and the fourth position in relative weight analysis. The unique effect of LRR is very low (rank twelfth). This variable has a large common effect, and it strips the common variance from other variables and it becomes one of the most critical variables in a few of the analyses.

Variable TPR shows a relatively lower (0.228) zero-order correlation but a higher value $(0.452)$ of the beta coefficient. The TPR reveals the characteristics of a suppressor variable. Comparing the squared structure coefficient with a beta coefficient gives an idea of the variable which shares the variance with other variables. Variables TLR, HWY, LRR, ELU, and ELR have an insignificantly small beta weight but they show a substantial value of the squared structure coefficient. These variables share the variance with other variables.

The possible reason for the inconsistency in the results is the suppression effect. Some of the variables strip other variables of the shared variance and they become the more important variable in a particular technique. Since different techniques assign the shared variance differently, a variable keeps changing its relative importance.

\section{Formation of regional competitiveness index}

Regional competitiveness indices have been formed as the linear combination utilizing the relative weights obtained from the analyses mentioned above. The Pearson correlation analysis and the Spearman rank correlation analysis have been performed between the indices formed and the indicator of revealed competitiveness (per capita GDP, Table 4).

Table 4

Pearson correlation and Spearman's rho between the indices and competitiveness

\begin{tabular}{|l|l|c|c|}
\hline \multicolumn{2}{|c|}{ Technique } & Pearson Correlation & Spearman's rho \\
\hline \multirow{2}{*}{ Zero-order correlation } & Correlation & $.753^{\prime \prime}$ & .604 \\
\cline { 2 - 4 } & Sig. (2-tailed) & .000 & .000 \\
\hline \multirow{2}{*}{ Structural coefficient } & Correlation & $.753^{\prime \prime \prime}$ & .604 \\
\cline { 2 - 4 } & Sig. (2-tailed) & .000 & .000 \\
\hline \multirow{2}{*}{ Beta coefficient } & Correlation & $.829^{\prime \prime}$ & .757 \\
\cline { 2 - 4 } & Sig. (2-tailed) & .000 & .000 \\
\hline Product measure & Correlation & -.314 &. .223 \\
\cline { 2 - 4 } & Sig. (2-tailed) & .004 & .045 \\
\hline Relative weight & Correlation & -.033 & .151 \\
\cline { 2 - 4 } & Sig. (2-tailed) & .772 & .659 \\
\hline Commonality analysis & Correlation & .784 & .000 \\
\cline { 2 - 4 } & Sig. (2-tailed) & .000 & \\
\hline
\end{tabular}

${ }^{* *}$. Significant at the 0.01 level (2-tailed)

*. Significant at the 0.05 level (2-tailed)

The Product measure and Relative weight techniques failed to demonstrate a positive correlation between the per capita GDP and the formed indices. The Beta coefficient (MLR) is the best among all the applied techniques for forming an index, as it is highly correlated (Pearson correlation $=0.829$ ), and it best represents the ranks of the districts of the region 
(Spearman's rho=0.757). The Commonality analysis also shows a significant Pearson correlation and Spearman's rho. This technique provides a detailed investigation of unique and shared effects among the independent variables. The Zero-order correlation and the Structure coefficient performed reasonably well in both tests.

\section{Assessment of sensitivity}

The sensitivity analysis has been performed with ANN in MATLAB to analyze the possible changes in regional competitiveness with changes in the critical components of economic infrastructure.

\section{Scheme of ANN}

The ANN applied in this research is a multilayer feed-forward network. It contains neurons arranged into the output and a single hidden layer. The network uses a gradient descent method. The Bayesian network has been used to reduce the potential for over-fitting. Fig. 5 presents the schematic diagram of the ANN.

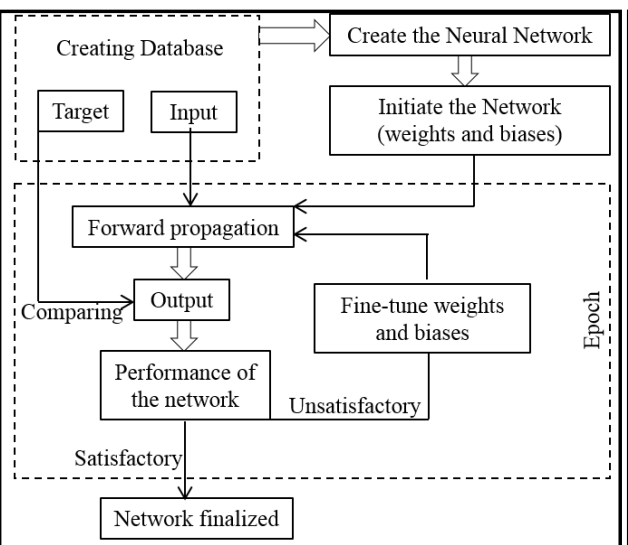

Fig. 5 - Scheme of ANN

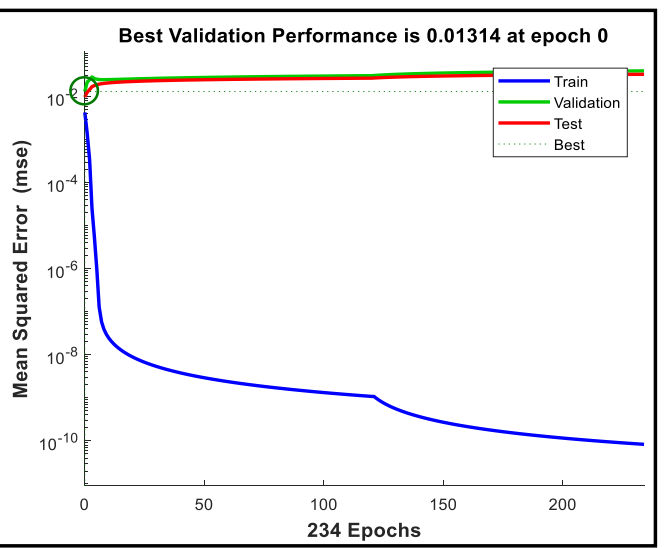

Fig. 6 - Validation performance of ANN

The input data-set consists of the variables of the critical components of economic infrastructure, and the target data-set consists of the per capita GDP for the 81 districts of the study area. Data has been normalized within a range $[0,1]$ using the min-max method. Out of the 81 samples, $70 \%$ of samples are randomly selected by the nn-tool for training the neural network, $15 \%$ of samples have been used for validation and, $15 \%$ are used for testing. No significant over-fitting has been observed (Fig. 6).

The network was permitted to train for no more than 10,000 epochs; at this point, the optimization task should stop. The maximum fail was set at 60,0000 , as training parameters. The training procedure forecasts result through an iterative process of adjusting the weights and biases of the neurons. Training stopped at 234 iterations (Fig. 7).

All the fit is within an acceptable range. The correlation coefficient $(R)$ between the target and the output is 0.969 for training data-set, 0.903 for validation data, 0.949 for test data, and 0.953 for overall data-set (Fig. 8).

The input variables were changed by $1 \%$ and $10 \%$, one at a time. Accordingly, the sensitivities in the competitiveness related to the variables are estimated. The relative weights and sensitivities are plotted in Fig. 9. 


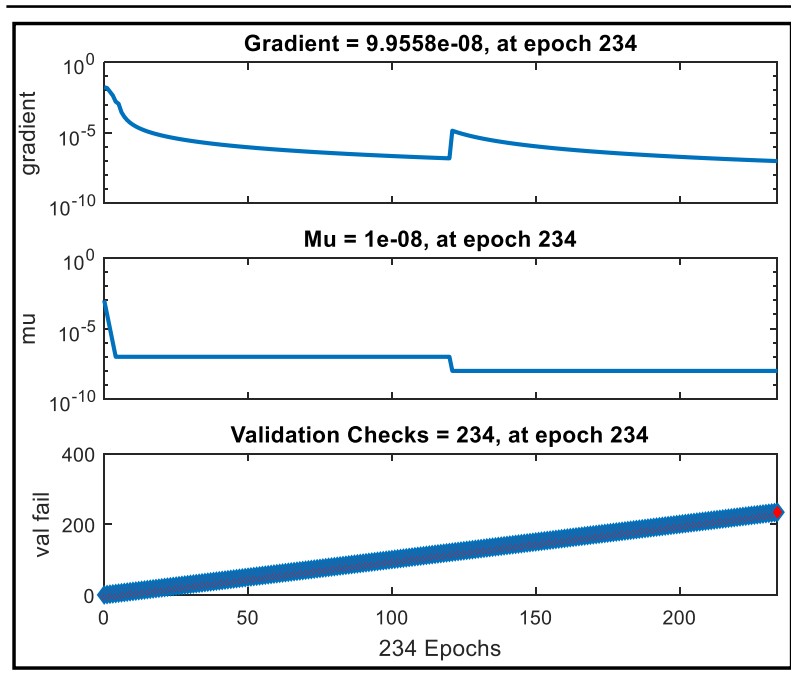

Fig. 7-Gradient, Mu and validation checks of the

Neural Network
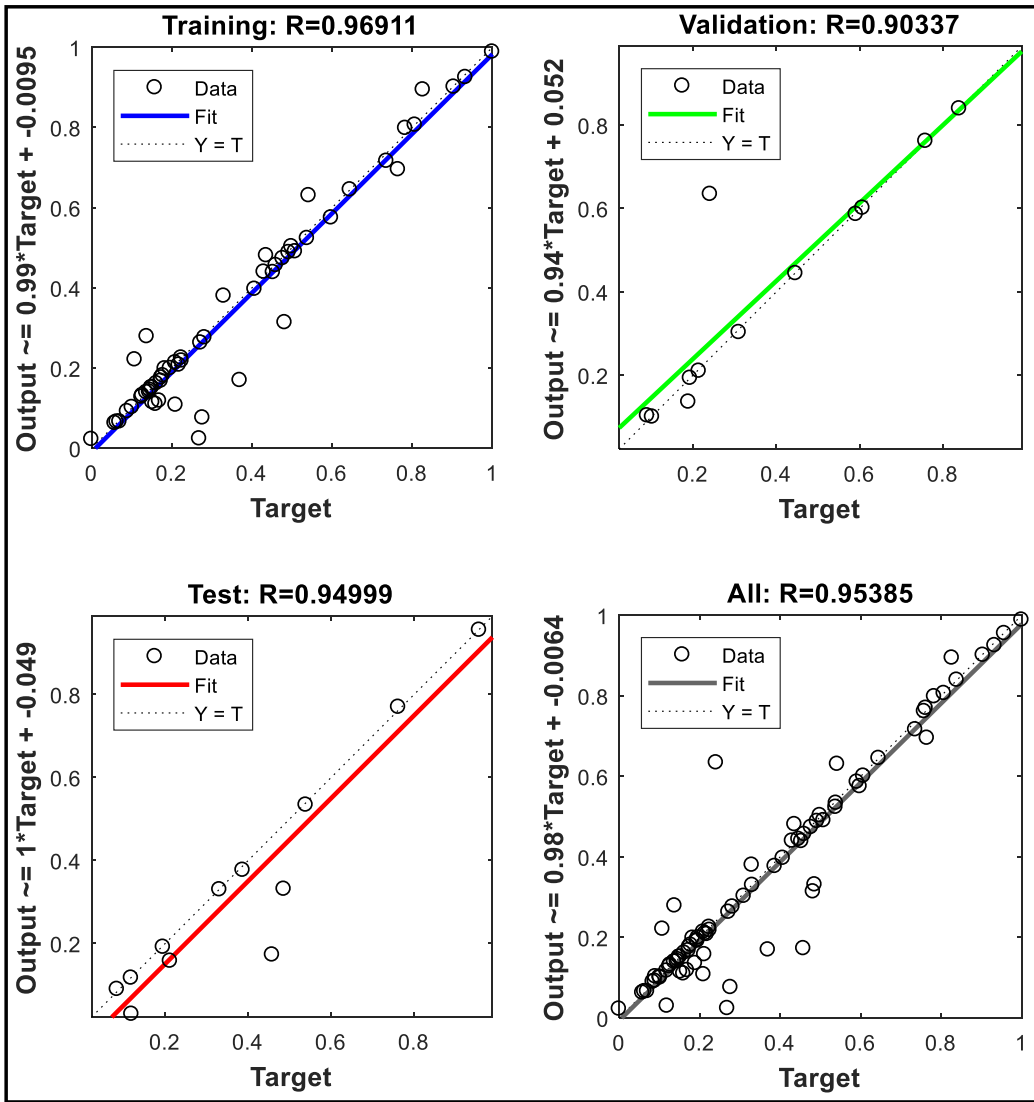

Fig. 8- Results of regression in ANN 


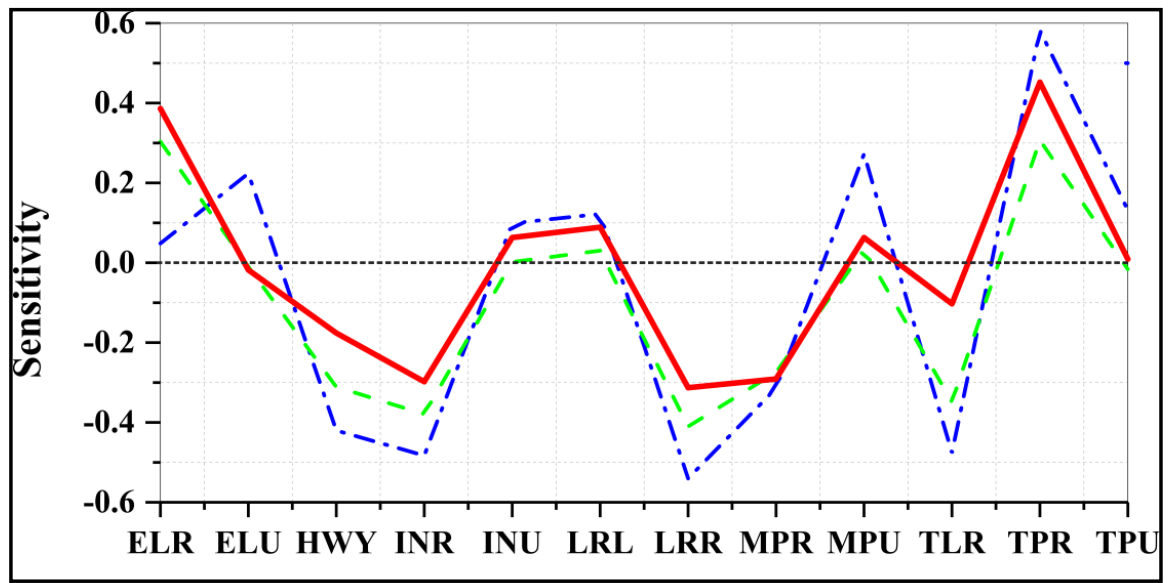

Fig. 9 - Sensitivities of the variables

\section{Discussion}

The level of infrastructure is highly correlated with economic growth (Fan and Zhang 2004). The better stock of public capital can improve investment (Bronzini and Piselli 2009). Infrastructure in the surrounding regions also improves productivity (Bronzini and Piselli 2009). The availability of transportation infrastructure improves the competitive advantage (Purwanto et al. 2017). The road has a positive association with the level of productivity of developed economies, like Italy (Bronzini and Piselli 2009). A negative association is found between transport infrastructure and GDP (Melo et al. 2013). In the present study, out of four components of transportation infrastructure, three components, i.e., highway, roads, and rural roads, show a reverse association and negative sensitivity with regional competitiveness. Out of the three mentioned transportation infrastructure, the reverse association (negative beta coefficient) is strongest for rural roads. The results indicate that better connectivity triggers capital and labor drain from the rural areas of the region. The phenomenon is also evident in the negative sensitivity related to all the three above mentioned transportation infrastructure. With the improvement in the stock of rural roads to 10 percent, the negative effect becomes more intense. The literature describes the negative association between transportation infrastructure and GDP caused by the out-migration from the region (Melo et al. 2013). Singh et al. (2011) observe massive labor out-migration from the Indo-Gangetic plain, especially from the rural areas of the region. Some transportation infrastructure can enhance the economic output, and others result only into the reallocation of output (Melo et al. 2013). In the present case, transportation infrastructure results in the reallocation of output, i.e., competitiveness, by the means of relocation of a major input, i.e., labor.

The marginal effect of transportation infrastructure decreases with the increase in its stock (Melo et al. 2013). A similar phenomenon is also observed in the study. In the present case, railway infrastructure shows a relatively smaller but positive association and sensitivity. Transportation infrastructure shows a marginal increase in the sensitivity with the 10 percent increase in the stock of the infrastructure. The cause of the different output sensitivity related to different sectors of the economy is the intensity of the use of transportation infrastructure (Melo et al. 2013). Since the region is predominantly rural and agriculture-based, railway infrastructure might not be utilized so intensely for the transportation of goods. This is reflected by the low beta value and the low sensitivity related to the railway infrastructure in the region. 
ICT is crucial for the competitiveness of emerging economies (Kowal and Paliwoda-Pękosz 2017). A positive relationship between broadband and GDP is observed by Koutroumpis (2009). Due to the economy of scale, more urbanized countries get more benefits from the broadband infrastructure (Koutroumpis 2009). A positive association between urban internet infrastructure and regional competitiveness has been observed in the present study. From the positive association, it can be inferred that the competitiveness of the study area is getting benefited through internet infrastructure in urban areas. The positive effects of IT infrastructure can be observed when the stock increases substantially (Indjikian and Siegel 2005). There exists a demand for a large stock of broadband infrastructure (Koutroumpis 2009). Similarly, in this study also, sensitivity related to urban internet infrastructure moves from negative to positive when the stock of infrastructure is improved substantially (improved by 10 percent). A negative association and a negative sensitivity are observed between the rural internet infrastructure and the competitiveness of the region. The reason behind the negative relationship can be explained as the information obtained from the improvement in the internet infrastructure is utilized for draining the capital and labor from the rural areas of the region. The negative sensitivity related to rural internet infrastructure gets stronger with the improvement in the stock of infrastructure by 10 percent.

Recently, the mobile infrastructure has played a critical role in global economic development (Lam and Shiu 2010). There are evidences that the growth in GDP is positively related to telecommunication infrastructure (Lam and Shiu 2010). Mobile infrastructure is more critical than landline for economic development (Ward and Zheng 2016). In the present study, both the landline and mobile phone infrastructure for urban areas show a positive association with regional competitiveness. The association is stronger for mobile phones. The positive association implies that the development of telecommunication infrastructure has a positive impact on the competitiveness of the region. The impact of mobile phone infrastructure is stronger than landline. For rural areas, the association is negative for mobile phones and positive for landline infrastructure. For developing countries, a $10 \%$ growth in mobile phone infrastructure produces a $0.6 \%$ growth in GDP (Waverman et al. 2005). In the present study, the improvement of $10 \%$ in urban and rural mobile phone infrastructure produces $0.27 \%$ and $0.31 \%$ increase in regional competitiveness, respectively. When the stock of rural mobile phone infrastructure increases by $10 \%$, the sensitivity becomes more negative. The association implies that in rural areas mobile phone is mostly utilized for gathering information related to work opportunities at distant locations.

For Central America, a $1 \%$ improvement in energy usage is related to $0.28 \%$ increases in GDP (Apergis and Payne 2009). Lee (2005) observed the elasticity of GDP for energy usage of eighteen developing countries as $<0.5 \%$. Lee and Chang (2008) observe the elasticity of energy usage for the GDP of sixteen Asian countries as $0.32 \%$. The elasticity of energy usage with GDP is greater than $0.25 \%$ for 22 OECD countries (Lee et al. 2008) and $0.12 \%$ for G7 nations (Narayan and Smyth 2008). In the present study, rural electricity infrastructure is positively related to regional competitiveness. The sensitivity for rural and urban electricity infrastructure is 0.3 and 0.01 , respectively.

\section{Conclusions}

In the present paper, multiple techniques have been tested for their performance in the assessment of relative weights and, consequently, for forming an index. The results obtained from the Product measure analysis and the relative weight analysis failed to demonstrate a positive correlation with competitiveness. The Zero-order correlation and the Structural coefficient analysis performed reasonably well. The beta coefficient is the best among all applied techniques for the assessment of relative weight and consecutively for forming an index. The Commonality analysis shows significantly high values of Spearman correlation and 
Pearson's rho. It is a very appropriate technique for the detailed investigation of unique and shared effects among variables. The result shows that the common effects of the critical components of the economic infrastructure are stronger than their unique effects. For example, variables TLR (rural telephone) and LRR (rural road) jointly share a $7.16 \%$ variance with the dependent variable. It implies that the competitiveness is better augmented when both the physical and digital connectivity is enhanced simultaneously in the rural areas of the region. The businesses in rural areas grow when the entrepreneurs get the ease of transport goods and, at the same time, they are able to collect information from various distant sources. It can be concluded that Infrastructure should be targeted jointly rather than individually to augment the competitiveness of the region.

Results from the perspective of both relative weights and sensitivities are utilized to analyze the situation better. Out of the four components of transportation infrastructure, three components, i.e., highway, roads, and rural roads, show a reverse association and negative sensitivity with regional competitiveness. The reverse association is strongest for rural roads. The results indicate that better connectivity triggers capital and labor drain from the rural areas of the region. Since the region is predominantly rural and agriculture-based, railway infrastructure might not be utilized so intensely for the transportation of goods. Low sensitivity related to railway infrastructure is evident in the results. A positive association between urban internet infrastructure and regional competitiveness is present. It can be inferred that regional competitiveness is getting benefited through internet infrastructure in urban areas. The reason behind the negative relationship between rural internet infrastructure and competitiveness can be explained as the information obtained from the improvement in the internet infrastructure is utilized for draining the capital and labor from the rural areas of the region. The negative association between rural mobile phone infrastructure and competitiveness can be explained similarly. Rural electricity infrastructure has a positive impact on regional competitiveness.

The present paper explores the solution for the problem of assignment of relative weights through a multi-model approach, in the case when multi-collinearity is present among the independent variables. Finally, the proposed methodology can be utilized in any domain of research to explore the relationship between the variables and, consecutively, for forming an index. The paper also discusses the importance of sensitivity along-with relative weights to prioritize the investment in order to augment the competitiveness of a region.

The authors came across certain limitations while performing research on regional competitiveness. The significant limitations related to data availability need to be highlighted. Since the region includes different administrative states, data availability in a similar format has been a significant constraint. Due to the same constraint of data availability, a time series analysis on regional competitiveness analysis is impossible.

For future research, the significant opportunity is that it is possible to generate multiple samples with the available data-set and to analyze the behavior of formed indices. It is suggested that the effects of 'factors of competitiveness' other than economic infrastructure on regional competitiveness need to be analyzed. Subsequently, the interaction of the effects of other factors of competitiveness and economic infrastructure on regional competitiveness can be additionally explored. Accordingly, a similar set of analyses can be carried out for the regions in a different river valley of the world, and the results can be compared to advance a good research vocabulary of regional development planning.

\section{References}

ACHOUR H., BELLOUMI M. (2016), Investigating the causal relationship between transport infrastructure, transport energy consumption and economic growth in Tunisia, Renewable and Sustainable Energy Reviews 56, 988-998. 
APERGIS N., PAYNE J. E. (2009), Energy consumption and economic growth in Central America: Evidence from a panel cointegration and error correction model, Energy Economics 31 (2), 211-216.

AZEN R., BUDESCU D. V. (2003), The dominance analysis approach for comparing predictors in multiple regression, Psychological Methods 8 (2), 129-148.

BARKLEY D. L., DUDENSING R. M. (2011), Industrial legacy matters: Implications for the development and use of indices of regional competitiveness, Economic Development Quarterly 25 (2), 130-142.

BARNA K. (2007), Measuring regional competitiveness, Journal of Central European Agriculture 8 (3), 343-356.

BHAWSAR P., CHATTOPADHYAY U. (2015), Competitiveness: Review, Reflections and Directions, Global Business Review 16 (4), 665-679.

BIRNIE E., JOHNSTON R., HEERY L., RAMSEY E. (2019), A critical review of competitiveness measurement in Northern Ireland, Regional Studies 53 (10), 1494-1504.

BOOYSEN F. (2002), An overview and evaluation of composite indices of development, Social Indicators Research 59, 115-151.

BOWEN H. P., MOESEN W. (2011), Composite competitiveness indicators with endogenous versus predetermined weights: An application to the World Economic Forum's global competitiveness index, Competitiveness Review 21 (2), 129-151.

BRONZINI R., PISELLI P. (2009), Determinants of long-run regional productivity with geographical spillovers: The role of $R \& D$, human capital and public infrastructure, Regional Science and Urban Economics 39 (2), 187-199.

CAI H., TREISMAN D. (2005), Does Competition for Capital Discipline Governments? Decentralization, Globalization, and Public Policy, American Economic Review 95 (3), 817-830.

CAPRARO R. M., CAPRARO M. M. (2001), Commonality analysis: Understanding variance contributions to overall canonical correlation effects of attitude toward mathematics on geometry achievement, Multiple Linear Regression Viewpoints 27 (2), 16-23.

CASTRO-GONZÁLES S., PEÑA-VINCES J. C., GUILLEN J. (2016), The competitiveness of Latin-American economies: Consolidation of the double diamond theory, Economic Systems 40 (3), 373-386.

CELLINI R., SOCI A. (2002), Pop competitiveness, PSL Quarterly Review 55 (220), 71 101.

CHASE-DUNN C. (1975), The Effects of International Economic Dependence on Development and Inequality: A Cross-National Study, American Sociological Review 40 (6), 720-738.

CHEN A., PARTRIDGE M. D. (2013), When Are Cities Engines of Growth in China? Spread and Backwash Effects across the Urban Hierarchy, Regional Studies 47 (8), 13131331.

CIVELEK M. E., UCA N., CEMBERCI M. (2015), The mediator effect of logistics performance index on the relation between global competitiveness index and gross domestic product, European Scientific Journal 11 (13), 368-375.

COURVILLE T., THOMPSON B. (2001), Use of structure coefficients in published multiple regression articles: $B$ is not enough, Educational and Psychological Measurement 61 (2), 229-248.

ČUČKOVIĆ N., JURLIN K., VUČKOVIĆ V. (2013), Measuring regional competitiveness: the case of Croatia, Southeast European and Black Sea Studies 13 (4), 503-523.

DARLINGTON R. B. (1968), Multiple regression in psychological research and practice, Psychological Bulletin 69 (3), 161-182.

DEVEREUX M. P., GRIFFITH R., SIMPSON H. (2004), The geographic distribution of production activity in the UK, Regional Science and Urban Economics 34 (5), 533-564.

DISATNIK D., SIVAN L. (2016), The multicollinearity illusion in moderated regression analysis, Marketing Letters 27, 403-408.

DUNNING J. H., BANNERMAN E., LUNDAN S. M. (1998), Competitiveness and Industrial Policy in Northern Ireland, Northern Ireland Economic Council, Belfast. 
FAN S., ZHANG X. (2004), Infrastructure and regional economic development in rural China, China Economic Review 15 (2), 203-214.

FERNANDEZ E., NAVARRO J., DUARTE A., IBARRA G. (2013), Core: a decision support system for regional competitiveness analysis based on multi-criteria sorting, Decision Support Systems 54 (3), 1417-1426.

FOURIE J. (2006), Economic infrastructure: a review of definitions, theory and empirics, South African Journal of Economics 74 (3), 530-556.

FREDERICK B. N. (1999), Partitioning variance in the multivariate case: A step-by-step guide to canonical commonality analysis, Advances in Social Science Methodology 5, 305-318. FREUDENBERG M. (2003), Composite indicators of country performance: a critical assessment, OECD Science, Technology and Industry Working Papers 2003/16, OECD Publishing, Paris.

GARCÍA-SÁNCHEZ A., SILES D., VÁZQUEZ-MÉNDEZ M. D. M. (2018), Innovation, Competitiveness and Prosperity: A Factor Analysis of Innovation Indicators in Spain, Management Studies 6 (5), 375-383.

GARDINER B., MARTIN R., TYLER P. (2004), Competitiveness, productivity and economic growth across the European regions, Regional Studies 38 (9), 1045-1067.

GHOSH D., VOGT A. (2012), Outliers: An evaluation of methodologies, Joint Statistical Meetings, 3455-3460.

GUERRERO M., URBANO D., FAYOLLE A. (2016), Entrepreneurial activity and regional competitiveness: evidence from European entrepreneurial universities, The Journal of Technology Transfer 41 (1), 105-131.

HAIR J. F., ANDERSON R. E., TATHAM R. L., BLACK W. C. (1995), Multivariate data analysis: with readings, Prentice Hall, Englewood Cliffs, NJ.

HERAVI G., ESLAMDOOST E. (2015), Applying Artificial Neural Networks for Measuring and Predicting Construction-Labor Productivity, Journal of Construction Engineering and Management 141 (10), 1-11.

HOPKINS K. D., WEEKS D. L. (1990), Tests for normality and measures of skewness and kurtosis: Their place in research reporting, Educational and Psychological Measurement 50 (4), 717-729.

HUGGINS R. (2003), Creating a UK Competitiveness Index: Regional and Local Benchmarking, Regional Studies 37 (1), 89-96.

HUOVARI J., KANGASHARJU A., ALANEN A. (2002), Constructing an Index for Regional Competitiveness, in: Acs Z. J., de Groot H. L. F., Nijkamp P. (eds.), The Emergence of the Knowledge Economy. Advances in Spatial Science, Springer, Berlin, pp. 121-138. INDJIKIAN R., SIEGEL D. S. (2005), The impact of investment in IT on economic performance: Implications for developing countries, World Development 33 (5), 681-700. JOHNSON J. W. (2000), A heuristic method for estimating the relative weight of predictor variables in multiple regression, Multivariate Behavioral Research 35 (1), 1-19. JOHNSON J. W., LEBRETON J. M. (2004), History and use of relative importance indices in organizational research, Organizational Research Methods 7 (3), 238-257. JU Y., SOHN S. Y. (2014), Development of a national competitiveness index based on a structural equation model, Technology Analysis \& Strategic Management 26 (5), 565-579. KAUR M., KHATUA A., YADAV S. S. (2016), Infrastructure Development and FDI Inflow to Developing Economies: Evidence from India, Thunderbird International Business Review 58 (6), 555-563.

KIM H.-Y. (2013), Statistical notes for clinical researchers: assessing normal distribution (2) using skewness and kurtosis, Restorative Dentistry \& Endodontics 38 (1), 52-54. KISZOVA Z., NEVIMA J. (2012), Usage of analytic hierarchy process for evaluating of regional competitiveness in case of the Czech Republic, Proceedings of 30th International Conference Mathematical Methods in Economics, 402-407. KITSON M., MARTIN R., TYLER P. (2004), Regional competitiveness: an elusive yet key concept?, Regional Studies 38 (9), 991-999.

KOUTROUMPIS P. (2009), The economic impact of broadband on growth: $A$ 
simultaneous approach, Telecommunications Policy 33 (9), 471-485.

KOVACS P., LUKOVICS M. (2006), Classifying Hungarian Sub-regions by their Competitiveness, The 25th SCORUS Conference on Regional and Urban Statistics and Research: Globalization Impact on Regional and Urban Statistics, 1-12.

KOWAL J., PALIWODA-PEKKOSZ G. (2017), ICT for Global Competitiveness and Economic Growth in Emerging Economies: Economic, Cultural, and Social Innovations for Human Capital in Transition Economies, Information Systems Management 34 (4), 304-307.

KRAHA A., TURNER H., NIMON K., ZIENTEK L. R., HENSON R. K. (2012), Tools to support interpreting multiple regression in the face of multicollinearity, Frontiers in Psychology 3 (44), 1-16.

KRAMULOVÁ J., JABLONSKÝ J. (2016), AHP model for competitiveness analysis of selected countries, Central European Journal of Operations Research 24, 335-351.

KRUGMAN P. (1997), The age of diminished expectations: U.S. economic policy in the 1990s, The MIT Press, Cambridge, MA.

KUMARI A., SHARMA A. K. (2017), Physical \& social infrastructure in India \& its relationship with economic development, World Development Perspectives 5, 30-33.

LAM P.-L., SHIU A. (2010), Economic growth, telecommunications development and productivity growth of the telecommunications sector: Evidence around the world, Telecommunications Policy 34 (4), 185-199.

LEBRETON J. M., PLOYHART R. E., LADD R. T. (2004), A Monte Carlo comparison of relative importance methodologies, Organizational Research Methods 7 (3), 258-282.

LEE C.-C. (2005), Energy consumption and GDP in developing countries: a cointegrated panel analysis, Energy Economics 27 (3), 415-427.

LEE C.-C., CHANG C.-P. (2008), Energy consumption and economic growth in Asian economies: A more comprehensive analysis using panel data, Resource and Energy Economics 30 (1), 50-65.

LEE C.-C., CHANG C.-P., CHEN P.-F. (2008), Energy-income causality in OECD countries revisited: The key role of capital stock, Energy Economics 30 (5), 2359-2373.

LENGYEL I. (2007), Economic growth and competitiveness of Hungarian regions (Economic development strategies for different types of regions), 2nd Central European Conference in Regional Science - CERS, 587-608.

LENGYEL I., LUKOVICS M. (2006), An Attempt for the Measurement of Regional Competitiveness in Hungary, "Enlargement, Southern Europe and the Mediterranean" 46th Congress of the European Regional Science Association, 1-29.

MARTIN R. L. (2003), A study on the factors of regional competitiveness, A draft final report for the European Commission Directorate-General Regional Policy, Retrieved from: www.ec.europa.eu.

MCDANIEL C., GATES R. (1998), Contemporary Marketing Research, South-Western Publishing, Cincinnati, $\mathrm{OH}$.

MELO P. C., GRAHAM D. J., BRAGE-ARDAO R. (2013), The productivity of transport infrastructure investment: A meta-analysis of empirical evidence, Regional Science and Urban Economics 43 (5), 695-706

MIKUŠ O., FRANIĆ R., GRGIĆ I. (2012), The evaluation of rural competitiveness in creating a policy of rural development in Croatia, Journal of Food, Agriculture \& Environment $10(2), 962-969$.

MOOD A. M. (1971), Partitioning variance in multiple regression analyses as a tool for developing learning models, American Educational Research Journal 8 (2), 191-202.

MOSEIKO V. O., KOROBOV S. A., FROLOV D. P. (2015), Socio-Economic Systems' Competitiveness Assessment Method, Asian Social Science 11 (20), 1-8.

NAGARAJ R., VAROUDAKIS A., VÉGANZONĖS M. $\square$ A. (2000), Long-run growth trends and convergence across Indian States, Journal of International Development 12 (1), 45-70.

NARAYAN P. K., SMYTH R. (2008), Energy consumption and real GDP in G7 countries: New evidence from panel cointegration with structural breaks, Energy Economics 30 (5), 2331-2341. 
NASSERI M., ASGHARI K., ABEDINI M. J. (2008), Optimized scenario for rainfall forecasting using genetic algorithm coupled with artificial neural network, Expert Systems with Applications 35 (3), 1415-1421.

NATHANS L. L., OSWALD F. L., NIMON K. (2012), Interpreting Multiple Linear Regression: A Guidebook of Variable Importance, Practical Assessment, Research \& Evaluation 17 (9), 1-19.

NIMON K. (2010), Regression commonality analysis: Demonstration of an SPSS solution, Multiple Linear Regression Viewpoints 36 (1), 10-17.

NIMON K., GAVRILOVA M., ROBERTS J. K. (2010), Regression results in human resource development research: Are we reporting enough?, in: Graham C., Dirani K. (eds.), Proceedings of the Human Resource Development 2010 International Conference, AHRD, Knoxville, TN, pp. 803-812.

NIMON K., REIO T. G. (2011), Regression Commonality Analysis: A Technique for Quantitative Theory Building, Human Resource Development Review 10 (3), 329-340.

NUNNALLY J. C., BERNSTEIN I. H. (1994), Psychometric theory (3rd ed.), McGrawHill, Inc., New York.

O'BRIEN R. M. (2007), A caution regarding rules of thumb for variance inflation factors, Quality \& Quantity 41, 673-690.

OECD (2008), Handbook on constructing composite indicators: methodology and user guide, OECD Publishing, Paris

OLDEN J. D., JACKSON D. A. (2002), Illuminating the "black box": A randomization approach for understanding variable contributions in artificial neural networks, Ecological Modelling 154 (1-2), 135-150.

PALEI T. (2015), Assessing the Impact of Infrastructure on Economic Growth and Global Competitiveness, Procedia Economics and Finance 23, 168-175.

PEDHAZUR E. J. (1997), Multiple regression in behavioral research: explanation and prediction, Wadsworth, Belmont.

PETRARCA F., TERZI S. (2018), The Global Competitiveness Index: an alternative measure with endogenously derived weights, Quality \& Quantity 52, 2197-2219.

POPESCU G. H., SIMA V., NICA E., GHEORGHE I. G. (2017), Measuring Sustainable Competitiveness in Contemporary Economies - Insights from European Economy, Sustainability 9, 1230.

PORTER M. E. (1990), The Competitive Advantage of Nations, Macmillan, Basingstoke. PORTER M. E. (1998), On Competition, Harvard Business Review Press, Boston.

PORTER M. E., DELGADO M., KETELS C., STERN S. (2008), Moving to a New Global Competitiveness Index, in: Porter M. E., Schwab K. (eds.), The global competitiveness report 2008-2009, World Economic Forum, Geneva, pp. 43-63.

PORTER M. E., KETELS C. H. M., MILLER K., BRYDEN R. T. (2004), Competitiveness in rural U.S. regions: Learning and research agenda, Harvard Business School, Retrieved from: www.hbs.edu.

PRATT J. W. (1987), Dividing the indivisible: Using simple symmetry to partition variance explained, in: Pukkila T., Puntanen S. (eds.), Proceedings of the 2 nd International Tampere Conference in Statistics, 245-260.

PURWANTO A. J., HEYNDRICKX C., KIEL J., BETANCOR O., SOCORRO M. P., HERNANDEZ A., EUGENIO-MARTIN J. L., PAWLOWSKA B., BORKOWSKI P., FIEDLER R. (2017), Impact of Transport Infrastructure on International Competitiveness of Europe, Transportation Research Procedia 25, 2877-2888.

RAHMAT S., SEN J. (2016), Cluster analysis based approach to delineate homogeneous regions for the assessment of regional competitiveness: a case of districts of India, Journal of Multidisciplinary Engineering Science Studies 2 (1), 173-180.

ROWELL R. K. (1996), Partitioning predicted variance into constituent parts: How to conduct commonality analysis, Advances in Social Science Methodology 4, 33-43. SCHALLER L., TARGETTI S., VILLANUEVA A. J., ZASADA I., KANTELHARDT J., 
ARRIAZA M., BAL T., BOSSI FEDRIGOTTI V., HANDAN GIRAY F., HÄFNER K., MAJEWSKI E., MALAK-RAWLIKOWSKA A., NIKOLOV D., PAOLI J.-C., PIORR A., RODRÍGUEZENTRENA M., UNGARO F., VERBURG P. H., VAN ZANTEN B., VIAGGI D. (2018), Agricultural landscapes, ecosystem services and regional competitiveness-Assessing drivers and mechanisms in nine European case study areas, Land Use Policy 76, 735-745.

SCHWAB K. (ed.) (2016), The Global Competitiveness Report 2016-2017, World Economic Forum, Geneva.

SCHWAB K., PORTER M. E., SACHS J. D. (2002), The Global Competitiveness Report 2001-2002, Oxford University Press, New York.

SIMIONESCU M. (2016), Competitiveness and Economic Growth in Romanian Regions, Journal of Competitiveness 8 (4), 46-60.

SINGH N. P., SINGH R. P., KUMAR R., PADARIA R. N., SINGH A., VARGHESE N.

(2011), Labour Migration in Indo-Gangetic Plains: Determinants and Impacts on Socioeconomic Welfare, Agricultural Economics Research Review 24, 449-458.

SINGHAL S., MCGREAL S., BERRY J. (2013), An evaluative model for city competitiveness: Application to UK cities, Land Use Policy 30 (1), 214-222.

SNIEŠKA V., BRUNECKIEN J. (2009), Measurement of Lithuanian Regions by Regional Competitiveness Index, Engineering Economics 1 (61), 45-57.

SOMOZA MEDINA X. (2016), Governance, Urban Competitiveness and Crisis in Spain, Journal of Urban and Regional Analysis 8 (1), 47-60.

STANICKOVA M. (2015), Classifying The EU Competitiveness Factors using Multivariate Statistical Methods, Procedia Economics and Finance 23, 313-320.

STANÍČKOVÁ M., MELECKÝ L. (2012), Assessment of efficiency in Visegrad countries and regions using DEA models, Ekonomická revue - Central European Review of Economic Issues 15, 145-156.

STORPER M. (1997), The Regional World: Territorial Development in a Global Economy, Guilford Press, New York.

TAM C. M., TONG T. K. L., TSE S. L. (2002), Artificial neural networks model for predicting excavator productivity, Engineering Construction and Architectural Management 9 (5 $-6), 446-452$.

THOMPSON N., WARD N. (2005), Rural areas and regional competitiveness, Centre for Rural Economy, New Castle University, Retrieved from: www.ncl.ac.uk.

TOGHYANI S., AHMADI M. H., KASAEIAN A., MOHAMMADI A. H. (2016), Artificial neural network, ANN-PSO and ANN-ICA for modelling the Stirling engine, International Journal of Ambient Energy 37 (5), 456-468.

TONIDANDEL S., LEBRETON J. M. (2010), Determining the relative importance of predictors in logistic regression: An extension of relative weight analysis, Organizational Research Methods 13 (4), 767-781.

TONIDANDEL S., LEBRETON J. M. (2015), RWA Web: A Free, Comprehensive, Web-

Based, and User-Friendly Tool for Relative Weight Analyses, Journal of Business and Psychology 30, 207-216.

WARD M. R., ZHENG S. (2016), Mobile telecommunications service and economic growth: Evidence from China, Telecommunications Policy 40 (2-3), 89-101.

WATSON C. J. (1990), Multivariate distributional properties, outliers, and transformation of financial ratios, The Accounting Review 65 (3), 682-695.

WAVERMAN L., MESCHI M., FUSS M. (2005), The Impact of Telecoms on Economic Growth in Developing Countries, The Vodafone Policy Paper Series 2 (3), 10-23.

WONG C. (2002), Developing indicators to inform local economic development in England, Urban Studies 39 (10), 1833-1863.

WORLD BANK (1994), World development report 1994: Infrastructure for development, Oxford University Press, New York.

WORLD BANK GROUP (2016), Global Economic Prospects: Divergences and Risks, The World Bank, Washington, D.C. 
YAFFEE R. A. (2002), Robust regression analysis: some popular statistical package options, IPAC Caltech, Retrieved from: www.ipac.caltech.edu.

YASKAL I., MAHA L.-G., PETRASHCHAK O. (2018), Spatial distribution of economic activities and internal economic integration in Romania, Journal of Urban and Regional Analysis 10 (2), 217-240.

ZHOU C.-C., YIN G.-F., HU X.-B. (2009), Multi-objective optimization of material selection for sustainable products: Artificial neural networks and genetic algorithm approach, Materials \& Design 30 (4), 1209-1215.

ZHOU Y., MAUMBE K., DENG J., SELIN S. W. (2015), Resource-based destination competitiveness evaluation using a hybrid analytic hierarchy process $(A H P)$ : The case study of West Virginia, Tourism Management Perspectives 15, 72-80.

ZIENTEK L. R., CAPRARO M. M., CAPRARO R. M. (2008), Reporting practices in quantitative teacher education research: One look at the evidence cited in the AERA panel report, Educational Researcher 37 (4), 208-216.

ZIENTEK L. R., THOMPSON B. (2006), Commonality analysis: Partitioning variance to facilitate better understanding of data, Journal of Early Intervention 28 (4), 299-307.

ZIGLARI L. (2017), Interpreting Multiple Regression Results: $\beta$ Weights and Structure Coefficients, General Linear Model Journal 43 (2), 13-22.

Initial submission: 13.02 .2020

Revised submission: 28.07.2020

Final acceptance: 26.08 .2020

Correspondence: Department of Architecture and Planning, Indian Institute of Technology, Kharagpur, West Bengal 721302, India.

Email: shahidrahmat82@gmail.com 
